Received February 3; revised February 16, 1971.

${ }^{1}$ Walls, G. L., The Vertebrate Eye and its Adaptive Radiation (Hafner, New York and London, 1967).

${ }^{2}$ Arnott, H. J., Maciolek, N. J., and Nicol, J. A. C., Science, $169,478(1970)$.

${ }^{3}$ Arnott, H. J., Maciolek, N. J., and Nicol, J. A. C., J. Cell Biol., 47, 9a (1970).

4 Jacks, T. J., Yatsu, L. Y., and Altschul, A. M., Plant Physiol., 42, 585 (1967).

${ }^{5}$ Ory, R. L., Yatsu, L. Y., and Kircker, H. W., Arch. Biochem. Biophys., 123, 255 (1968).

6 Trelease, R. N., thesis, Univ. Texas (1969).

7 Zilversmit, D. B., in Structural and Functional Aspects of Lipoproteins in Living Systems (edit. by Tria, E., and Scanu, A. M.) (Academic Press, New York and London, 1969).

8 Folch, J., Ascoli, J., Lees, M., Meath, J. A., and LeBaron, F. N., J. Biol. Chem., 191, 833 (1951).

9 Stahl, E., Thin-layer Chromatography: a Laboratory Handbook (Academic Press, New York and London, 1965).

10 Litchfield, C., Lipids, 3, 417 (1968).

litter weight results is that fungi of the mycorrhizal partnership, having a biological advantage because they are not dependent on litter for an energy source, become dominant in the litter and suppress the activity of saprophytic organisms. Litter decomposition slows down and conditions favouring mor formation result.

Forest Research Institute,

RuTH L. GADGIL

P. D. GADGIL

Private Bag, Rotorua,

New Zealand

Received March 29; revised May 17, 1971.

1 Handley, W. R., Forestry Commission Bull., No. 23 (1954).

2 Kononova, M. M., Soil Organic Matter (Pergamon, Oxford, 1966).

${ }^{3}$ Kühnelt, W., Soil Biology (Faber and Faber, London, 1961).

4 Meyer, F. H., in Soil Micromorphology (edit. by Jongerius, A.), 23 (Elsevier, Amsterdam, 1964).

${ }^{5}$ Mikola, P., in Mykorrhiza: Internationales Mykorrhizasymposium Weimar 1960, 277 (G. Fischer, Jena, 1963).

${ }^{6}$ Lobanow, N. W., Mykotrophie der Holzpflanzen (VEB Deutscher Verlag der Wissenschaften, Berlin, 1960).

\title{
Mycorrhiza and Litter Decomposition
}

FORMATION of the mor type of forest litter, characterized by slow decomposition, has been attributed to a number of factors ${ }^{1-3}$, but the effect of mycorrhizal fungi, though postulated $^{4,5}$, has not been studied experimentally. We have conducted an experiment in which root activity and thus mycorrhizal activity were reduced in small areas of an unthinned Pinus radiata stand. The following treatments (three replicates in a randomized block design) were applied to $1 \times 1 \mathrm{~m}$ plots sited between the trees.

(A) The plot boundary was cut to a depth of $30 \mathrm{~cm}$ at commencement and recut every 2 weeks. All litter was removed to a sheet of hessian with minimum disturbance. As many roots as possible were removed from the soil to a depth of $30 \mathrm{~cm}$ and the litter was carefully replaced.

$(B)$ The plot boundary was cut as above and the litter was removed. The soil was dug over to a depth of $30 \mathrm{~cm}$ but no roots were removed. The litter was replaced.

(C) The plot boundary was cut as above. The plot was not dug, nor were any roots removed. The litter was removed and replaced.

(D) The control plot was neither dug nor cut, but the litter was removed and replaced.

Table 1 Dry Weight of Litter from Sample Plots after 12 Months

A

$474.8 \pm 211.5$
Treatments

B $C$

D

$$
351.6 \pm 133.7
$$

$659.0 \pm 328.4$

$1,681.7 \pm 213.9$

The figures represent the means (in grams) of three replicates \pm the standard deviation.

After 12 months the weight of litter per plot which had received treatment $D$ was significantly $(P<0.001)$ greater than in those given treatments $A, B$ and $C$. Experimental design ruled out the effect of soil disturbance or decomposition of severed roots. It seems clear that the presence of living roots suppressed litter decomposition in some way. Pinus is a highly mycotrophic genus ${ }^{6}$, and for practical purposes $P$. radiata roots in the field may be considered as mycorrhizas. The observed effect could be a result of some physiological activity of the tree roots functioning as a separate entity. On the other hand, it was observed that basidiomycetous mycelial wefts, normally very conspicuous in the litter, were completely absent from plots which had received treatments $A, B$ and $C$ although they were obvious in plots given treatment $D$. We suggest that these wefts were the external mycelium of the mycorrhizas. An alternative explanation for the

\section{Immunological Suppression of the Occurrence of Spontaneous Mammary Tumours in $\mathrm{C} 3 \mathrm{H} / \mathrm{He}$ Mice}

Mice immunized with syngeneic tumours acquire resistance to subsequent transplantation of mammary tumours ${ }^{1-3}$, but there have been no reports of the immunological suppression of the spontaneous occurrence of the tumours by the use of appropriate specific antigens. Mouse mammary tumours appear in favourable conditions in a high percentage of both virgin and bleeding female $\mathrm{C} 3 \mathrm{H} \mathrm{mice}{ }^{4}$. Mice of the $\mathrm{C} 3 \mathrm{H} / \mathrm{He}$ strain are genetically pure (syngeneic) and acquire the mammary tumour inducing virus (MTV) by vertical transmission.

We have assumed that the occurrence of spontaneous mammary tumours in $\mathrm{C} 3 \mathrm{H} / \mathrm{He}$ mice would be suppressed by immunization with the specific antigens of the mammary tumour.

The tumour specific transplantation antigen (TSTA) of mouse mammary tumours can be extracted from MM102 cells-the ascitic line derived from a spontaneous mammary tumour in a $\mathrm{C} 3 \mathrm{H} / \mathrm{He}$ mouse ${ }^{5}$. The TSTA extracted from MM-

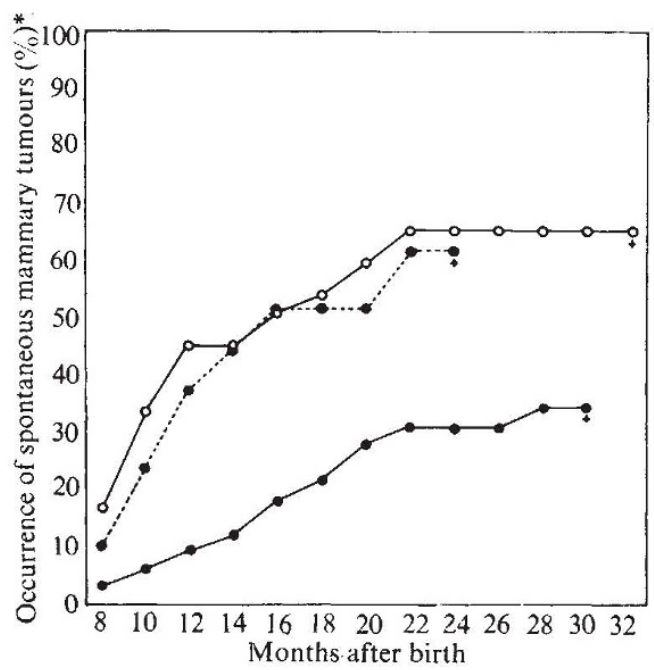

Fig. 1 Occurrence of spontaneous mammary tumours in $\mathrm{C} 3 \mathrm{H} / \mathrm{He}$ mice. Each plot is figured out the total occurrence within the months. - Immunized with MM-antigen; ... ...., treated with $\mathrm{C} 3 \mathrm{Hf}$ organ extract; - $\mathrm{O}-$, untreated. + , All mice were dead by the marked month. 